\title{
Anisakis simplex sensu lato associated with red vent syndrome in wild adult Atlantic salmon Salmo salar in England and Wales
}

\author{
Melinda Beck ${ }^{1, *}$, Rob Evans ${ }^{2}$, Stephen W. Feist ${ }^{3}$, Paul Stebbing ${ }^{3}$, Matt Longshaw ${ }^{3}$, \\ Eileen Harris ${ }^{4}$ \\ ${ }^{1}$ Environment Agency, Bromholme Lane, Brampton, Cambridgeshire PE28 4NE, UK \\ ${ }^{2}$ Environment Agency, Cambria House, Newport Road, Cardiff CF24 0TP, UK \\ ${ }^{3}$ Cefas Weymouth Laboratory, Barrack Road, The Nothe, Weymouth, Dorset DT4 8UB, UK \\ ${ }^{4}$ Natural History Museum, Parasitic Worms Division, Department of Zoology, Cromwell Road, London SW7 5BD, UK
}

\begin{abstract}
Wild Atlantic salmon Salmo salar with swollen and/or bleeding vents (red vent syndrome) have been observed in rivers across England and Wales. Low numbers of salmon with this condition have previously been recorded, but reports have increased in 2006 and 2007. Affected and non-affected salmon were sampled from fish traps and their vent pathology was examined. Third stage larvae of the nematode Anisakis simplex sensu lato were observed in the tissue surrounding the vent in all affected fish. Histology of the vent showed gross lesions with an inflammatory response associated with non-encapsulated nematode worms in the connective tissue and skeletal muscle. The presence of the parasite in the unusual location of the vent areas, with associated haemorrhaging, is possibly a new emerging pathological association with the nematode A. simplex infection in Atlantic salmon. The reason for this unusual tissue tropism by larval $A$. simplex and the significance on already depleted salmon stocks are currently unknown.
\end{abstract}

KEY WORDS: Red vent $\cdot$ Salmo salar $\cdot$ Wild salmon · Anisakis simplex

\section{INTRODUCTION}

Larvae of the nematode Anisakis simplex sensu lato have been found worldwide in a wide variety of marine fish and in migratory fish in freshwater (Moravec 1994, Molnár 2006). The life cycle of $A$. simplex involves crustacean, fish and marine mammal hosts, and has been documented by previous authors (e.g. Kagei 1969, Oshima 1969, Smith 1971, 1984, Smith \& Wootten 1984, Moravec 1994, Klimpel et al. 2004). Eggs of A. simplex are passed by marine mammals into seawater; they then embryonate to 3rd-stage larvae and are ingested by small crustaceans, such as members of the Euphasia and Thysanoessa genera. Following further development in the haemocoel, if the intermediate host is consumed by a fish, the parasite normally encapsulates on visceral tissues, particularly the mesen- teries and liver. The fish serve as paratenic hosts. The 4th-stage and adult parasites are found in the alimentary tract of marine mammals, which acquire them via ingestion of infected fish.

The present study was initiated to (1) investigate reports of swollen and/or bleeding vents, commonly referred to as red vent syndrome (RVS), in wild adult Atlantic salmon Salmo salar from rivers across England and Wales; (2) confirm the identity of the nematode species found in the vent tissue; and (3) characterise the pathological impact in affected salmon.

\section{MATERIALS AND METHODS}

To estimate the geographical range of RVS-affected salmon, records of returning Atlantic salmon were col- 
Table 1. Salmo salar. Trap location, distance of trap from the sea, sample date and number of fish with swollen vents sampled

\begin{tabular}{|lccll|}
\hline Trap & Location & $\begin{array}{c}\text { Distance from } \\
\text { sea }(\mathrm{km})\end{array}$ & $\begin{array}{l}\text { Sampling } \\
\text { date }\end{array}$ & $\begin{array}{l}\text { Number } \\
\text { examined }\end{array}$ \\
\hline $\begin{array}{l}\text { River } \\
\text { Caldew }\end{array}$ & $\begin{array}{l}54^{\circ} 52^{\prime} 24^{\prime \prime} \mathrm{N}, \\
2^{\circ} 56^{\prime} 24^{\prime \prime} \mathrm{W}\end{array}$ & 16.3 & Nov 2006 & 3 \\
River & $\begin{array}{l}50^{\circ} 31^{\prime} 5^{\prime \prime} \mathrm{N}, \\
\text { Tamar }\end{array} 4^{\circ} 12^{\prime} 23^{\prime \prime} \mathrm{W}$ & 29.9 & Aug 2007 & 2 \\
$\begin{array}{l}\text { River } \\
\text { Dee }\end{array}$ & $\begin{array}{l}53^{\circ} 11^{\prime} 8^{\prime \prime} \mathrm{N}, \\
2^{\circ} 53^{\prime} 20^{\prime \prime} \mathrm{W}\end{array}$ & 24.4 & Sep 2007 & $\begin{array}{l}3 \text { affected, } \\
\text { unaffected } \\
\text { (control) }\end{array}$ \\
\hline
\end{tabular}

slides. Sections were stained with haematoxylin and eosin (H\&E) and examined using a Nikon Eclipse E800 microscope. Digital images and measurements were taken using the Lucia ${ }^{\mathrm{TM}}$ Screen Measurement System (Nikon).

\section{RESULTS AND DISCUSSION}

Atlantic salmon with swollen and/or bleeding vents were recorded from 23 rivers across England and Wales, locations of which are shown in Fig. 1. The absence of reports in southeast England

lated from Environment Agency fish traps, brood stock sampling, verified rod catch and field staff observations for 2006 and 2007. A long-term dataset from the River Dee fish trap (Table 1) was examined for historical occurrence of swollen and/or bleeding vents in Salmo salar.

To examine the pathology, a total of 8 affected and 2 non-affected (control) salmon were sampled from Environment Agency fish traps in 3 rivers (Table 1). Sample numbers were restricted due to concerns about depletion of stocks. Fish were killed by an overdose of the anaesthetic Benzocaine (5 g ethyl p-aminobenzoate dissolved in $80 \mathrm{ml}$ acetone $10 \mathrm{l}^{-1}$ water) and a post-mortem was conducted using the protocol established by Hoole et al. (2001). Bacteriological swabs were taken from the area surrounding and internal to the vent as well as aseptically from the kidney, and inoculated on tryptone soya agar (TSA) and TSA with $2 \%$ salt. Plates were incubated at $22^{\circ} \mathrm{C}$ for $14 \mathrm{~d}$. Bacterial isolates were identified by Gram stain, morphology, motility, oxidase and catalase tests, fermentation and oxidation of glucose $(\mathrm{O} / \mathrm{F})$ tests and the BioMerieux Apilab API 20E and API 20NE biochemical test strip system. For virology screening, samples from the kidney, brain and spleen were extracted using standard techniques, diluted at 1:100 and 1:1000 and inoculated onto bluegill fin (BF-2), epithelial papilloma carp (EPC) and chinook salmon embryo (CHSE-214) cell lines. After $7 \mathrm{~d}$ incubation at $15^{\circ} \mathrm{C}$, monolayers were subcultured onto fresh cells and incubated for a further $7 \mathrm{~d}$. Cell monolayers were examined for evidence of a cytopathic effect using a Nikon inverted microscope. For histological examination, the vent was resected to include surrounding musculature, epithelia and approximately $1 \mathrm{~cm}$ of the lower digestive tract leading to the vent. Samples were also taken of liver, kidney, spleen and gill. All tissues were fixed in 10\% neutral buffered formalin for a minimum of $24 \mathrm{~h}$ before wax processing using standard protocols; tissues were sectioned at $5 \mu \mathrm{m}$ thickness and mounted on glass reflects the lack of salmon in rivers in this area. There may be rivers, however, where affected fish have gone unnoticed or unreported. Data from the River Dee fish

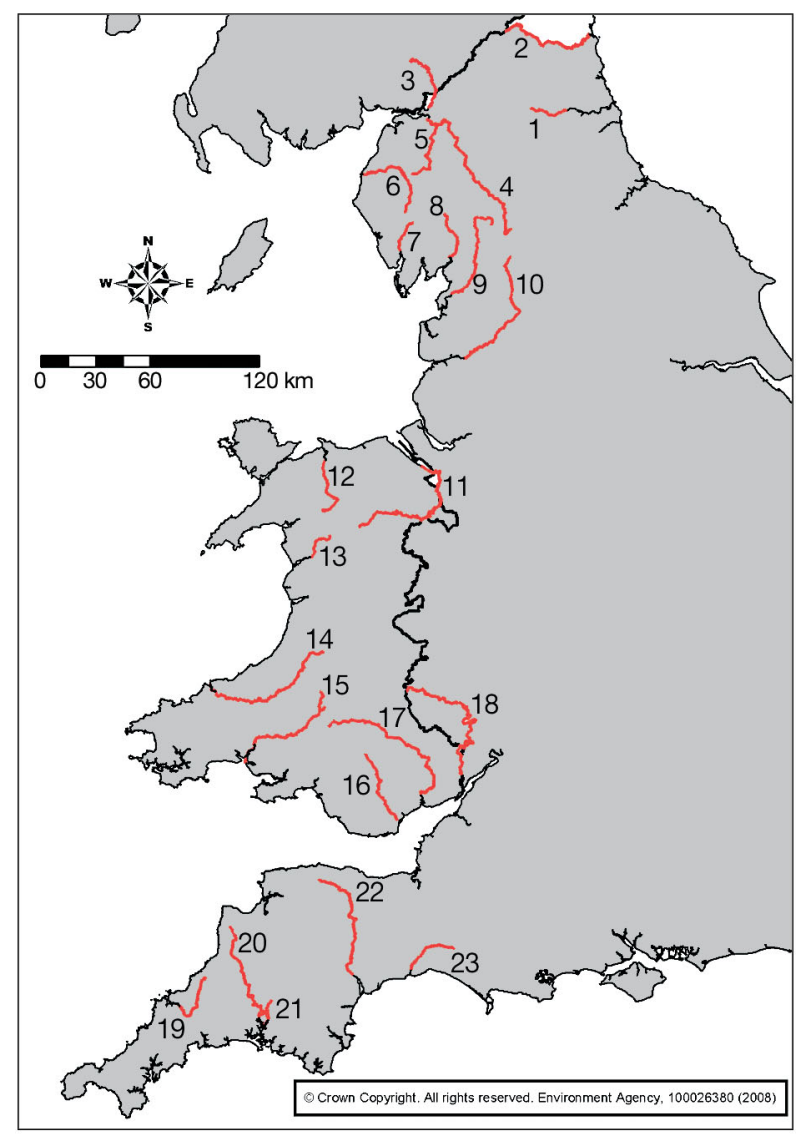

Fig. 1. Salmo salar. Rivers in England and Wales where red vent Atlantic salmon were recorded in 2006 and 2007 by Environment Agency staff. (1) River Tyne, (2) River Coquet, (3) River Esk, (4) River Eden, (5) River Caldew, (6) River Derwent, (7) River Duddon, (8) River Kent, (9) River Lune, (10) River Ribble, (11) River Dee, (12) River Conwy, (13) River Mawddach, (14) River Teifi, (15) River Tywi, (16) River Taff, (17) River Usk, (18) River Wye, (19) River Camel, (20) River Tamar, (21) River Tavy, (22) River Exe, (23) River Axe 
trap have been collected since 1992 without any change in annual effort or recording protocol, and all external abnormalities in sampled salmon were noted. No affected fish were recorded with swollen vents in this dataset prior to 2004 (Table 2). Other publications using the same dataset include Milner \& Evans (2003), Davidson et al. (2006), and Cefas \& Environment Agency (2008). An apparent increase in the number of reports of affected fish occurred in 2006 and 2007 in other rivers, perhaps partly as a response to a greater awareness of RVS affecting Atlantic salmon.

Red vent syndrome was present in both male and female salmon (Table 2) but not observed in sea trout Salmo trutta. The majority of affected salmon have been grilse, but 2 sea-winter fish displaying the condition were also confirmed from the rivers Dee, Lune and Tamar.

Gross observations in affected salmon from fish traps varied from general redness of the skin and some swelling around the vent opening, to haemorrhaging lesions with prolapse of tissue from the vent (Fig. 2). The posterior region of the gastrointestinal tract ( 1 to $1.5 \mathrm{~cm}$ anterior to the vent) was inflamed. Nematode worms, identified as 3rd-stage larva of the Anisakis simplex complex, were observed in the tissue surrounding the vent; specimens have been deposited in the Natural History Museum, London (registration no. 2008.4.25.1-3). Apart from the vent lesions, the salmon appeared in overall good condition. In one fish that did not exhibit a reddened or swollen vent (control), a small area of haemorrhaging on the external surface of the gastrointestinal tract was noted near the vent. A single nematode worm was found in the same position. No nematode worms were found in the vent region of the second control fish.

Longitudinal sections through the vent region revealed the association between the nematodes, gut wall and surrounding tissues of the body wall. In all cases, the majority of nematodes appeared to be in good condition, with only a few appearing necrotic. Their presence in the somatic musculature, muscularis of the lower intestine and the visceral cavity evoked an intense inflammatory reaction (Figs. 2 \& 3). This appeared to be chronic in nature with extensive granulation tissue and fibrosis surrounding the parasites (Fig. 4). Occasionally, focal areas of necrosis were seen. The tissues surrounding the nematodes were well vascularised and contained large numbers of degranulating eosinophils and occasional melanomacrophages (Fig. 5). The histopathology is similar to that previously reported by Kahl (1938), Berland (1961), Hauck \& May (1977) and summarised by Kinne (1984) for Anisakis simplex and other encapsulated nematodes (Gardiner \& Poynton 1999).

All virology tests were negative. There was no bacterial growth from the kidney swabs or bacterial evidence in histological sections, suggesting the absence of a systemic bacterial infection. Bacterial cultures from the vent yielded mixed growth of Aeromonas hydrophila and A. sobria and an unidentified Vibrio species. These organisms were considered as secondary, opportunistic infections or components of the normal vent microflora, as they were not consistently associated with the lesions.

Insufficient fish were available to determine association between severity of condition, intensity of infection and length of time in freshwater.

The pathology that appears to be associated with vent infections of Anisakis simplex in salmon has not been previously recorded in published literature and the reasons for such a response are unknown. The wide geographical range of the reports (see Fig. 1) suggests that the cause is not specific to individual rivers. Additionally, similar vent pathology and associated nematode infections in salmon have been recorded from Scotland in over 50 rivers in 2007 (FRS 2007) as well as from rivers in Iceland (G. Jónsson pers. comm.), Ireland (P. Gargen pers. comm.) and Northern Ireland (A. Niven pers. comm.).

Adult Atlantic salmon and sea trout with reddened or haemorrhagic vents associated with Listonella (= Vibrio) anguilarum during periods of high water temperature and low flows have previously been recorded from mortalities reported in the River Tyne in northeast England (St. Hilaire et al. 2005); however, nematodes were not recorded in fish from this location and

Table 2. Salmo salar. Number, sex and age of affected salmon from the River Dee. F: female; M: male; NK: not known; 1SW: 1 seawinter; MSW: multi-seawinter

\begin{tabular}{|ccccccc|}
\hline Year & $\begin{array}{c}\text { Total salmon } \\
\text { trapped }\end{array}$ & $\begin{array}{c}\text { Affected } \\
\text { salmon }\end{array}$ & $\begin{array}{c}\text { Affected salmon } \\
(\%)\end{array}$ & $\begin{array}{c}\text { Sex of affected } \\
\text { salmon }\end{array}$ & $\begin{array}{c}\text { 1SW affected } \\
\text { salmon }\end{array}$ & $\begin{array}{c}\text { MSW affected } \\
\text { salmon }\end{array}$ \\
\hline 2004 & 1206 & 4 & 0.3 & $3 \mathrm{~F}, 1 \mathrm{NK}$ & 4 & 0 \\
2005 & 1711 & 52 & 3 & $30 \mathrm{~F}, 20 \mathrm{M}, 2 \mathrm{NK}$ & 49 & 78 \\
2006 & 1382 & 119 & 9 & $97 \mathrm{~F}, 16 \mathrm{M}, 6 \mathrm{NK}$ & 31 \\
2007 & 1421 & 379 & 27 & $259 \mathrm{~F}, 107 \mathrm{M}, 13 \mathrm{NK}$ & 301 & 78 \\
\hline
\end{tabular}



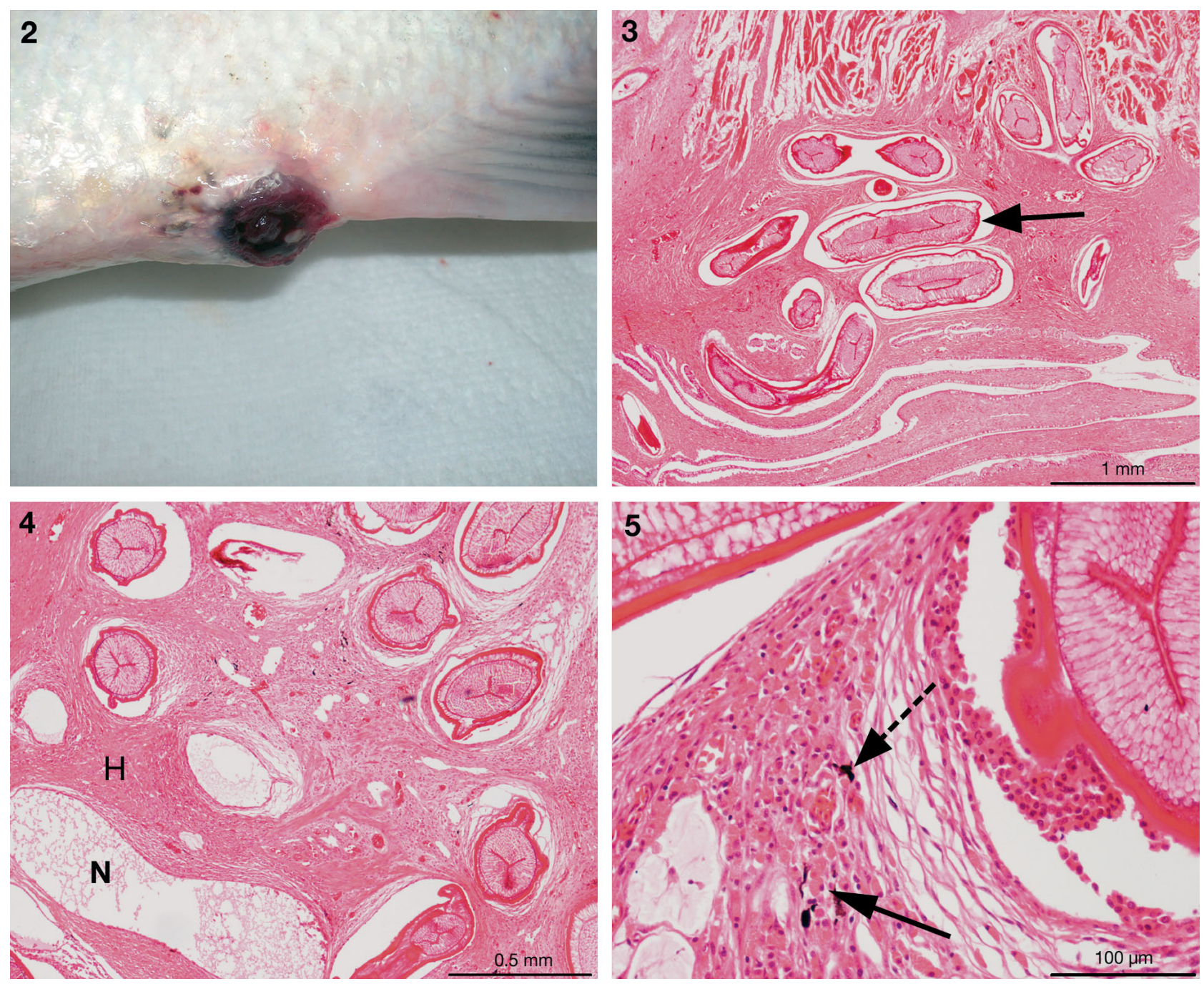

Figs. 2 to 5. Anisakis simplex in Salmo salar. Fig. 2. External appearance of the vent area of an affected salmon. The vent is haemorrhagic and swollen. Fig. 3. Longitudinal section of the vent region showing $A$. simplex nematodes embedded in the smooth muscle of the body wall (arrow). H\&E staining, scale bar $=1 \mathrm{~mm}$. Fig. 4. Extensive granulation tissue and fibrosis surrounding the nematodes. Areas of necrotic tissue $(\mathrm{N})$ and haemorrhaging $(\overline{\mathrm{H}}) \mathrm{can}$ be seen, possibly resulting from nematode migration or necrosis. H\&E staining, scale bar $=0.5 \mathrm{~mm}$. Fig. 5. Detail of tissue reaction in the vicinity of a nematode (upper right). Influx of eosinophil granulocytes (arrow), many of which have degranulated, and occasional melanomacrophages (dashed arrow) are present. H\&E staining, scale bar $=100 \mu \mathrm{m}$

tissues for the vent region were not examined histologically. The increased occurrence of swollen and/or bleeding vents in Atlantic salmon across England and Wales in 2006 and 2007 appears different: although there were record high temperatures in July 2006 (www.metoffice.gov.uk/corporate/pressoffice/2006/ pr20060801.html), temperatures have been lower in 2007 and water levels and flow higher (www.environment-agency.gov.uk/commondata/acrobat/july_2007_ final_1838570.pdf), but the prevalence of salmon with swollen vents has increased. Furthermore, there was no evidence either of wild salmon mortality, although these might have gone unnoticed in some estuaries, or of bacterial infections (other than the secondary opportunistic bacteria in the vents).

The reasons for the increase of infection in this unusual location by larval Anisakis simplex and the potential significance of the swollen vents on the survival and spawning of already depleted salmon stocks can only be surmised. Further surveillance and investigation are required to identify the cause and prevalence of infection, the association between severity of the pathology and intensity, time of infection or environmental conditions, as well as the impact of this condition on wild Atlantic salmon stocks. 
Acknowledgements. The authors thank the riparian owners for allowing us to sample the salmon, colleagues in the Environment Agency for monitoring of the fish traps, J. Armitage for help sampling the salmon and A. B. Twigg for his assistance in producing Fig. 1. The support of Defra (contract FC1166) is also acknowledged.

\section{LITERATURE CITED}

Berland B (1961) Nematodes from some Norwegian marine fishes. Sarsia 2:1-50

Cefas \& Environment Agency (2008) Salmon stocks and fisheries in England and Wales 2007: preliminary report for ICES April 2008. Environment Agency, Bristol

Davidson IC, Hazelwood MS, Cove RJ (2006) Predicted growth of juvenile trout and salmon in four rivers in England and Wales based on past and possible future temperature regimes linked to climate change. In: Harris GS, Milner NJ (eds) Sea trout: biology, conservation and management. Proc 1st Int Sea Trout Symp, Cardiff, July 2004. Fishing News Books, Blackwell Scientific Publications, Oxford, p 401-416

FRS (Fisheries Research Services) (2008) Red vent syndrome (RVS) in wild Atlantic salmon (Salmo salar). www.frs-scotland.gov.uk/FRS.Web/Uploads/Documents/ Red\%20vent\%20Scotweb.pdf

Gardiner CH, Poynton SL (1999) An atlas of metazoan parasites in animal tissues. Registry of Veterinary Pathology, Armed Forces Institute of Pathology, American Registry of Pathology, Washington, DC

Hauck AK, May EB (1977) Histopathological alterations associated with Anisakis larvae in Pacific herring from Oregon. J Wildl Dis 13:290-293

Hoole D, Bucke D, Burgess P, Wellby I (2001) Diseases of carp and other cyprinid fishes. Fishing News Books, Blackwell

Editorial responsibility: Robin Overstreet,

Ocean Springs, Mississippi, USA
Publishing, Oxford

Kagei N (1969) Life cycle of the genus Anisakis. Saishin Igaku 24:389-400

Kahl W (1938) Nematoden in Seefischen. II. Erhebungen über den Befall von Seefischen mit Larven von Anacanthocheilius rotundatus (Rudolphi) und die durch diese Larven hervorgerufenen Reaktionen des Wirtesgewebes. Z Parasitenkd 10:513-534

Kinne O (1984) Diseases of marine animals. Vol IV, Part 1: Introduction, Pisces. Biologische Anstalt Helgoland, Hamburg

Klimpel S, Palm HW, Ruckert S, Piatkowski U (2004) The life cycle of Anisakis simplex in the Norwegian Deep (northern North Sea). Parasitol Res 94:1-9

Milner N, Evans R (2003) The incidence of escaped Irish farmed salmon in English and Welsh rivers. Fish Manag Ecol 10:403-406

Molnár K (2006) Phylum Nematoda. In: Woo PTK (ed) Fish diseases and disorders, Vol 1: Protozoan and metazoan infections, 2nd edn. CAB International, Oxford, p 417-443

Moravec F (1994) Parasitic nematodes of freshwater fishes of Europe. Kluwer Academic Publishers, Dordrecht

Oshima T (1969) A study on the first host of Anisakis. Saishin Igaku 24:401-404

Smith JW (1971) Thysanoessa inermis and T. longicaudata (Euphausiidae) as first intermediate hosts of Anisakis sp. (Nematoda: Ascaridata) in the Northern Sea, to the north of Scotland and at Faroe. Nature 234:478

Smith JW (1984) Larval ascaridoid nematodes in myopsid and oegopsid cephalopods from around Scotland and in the northern North Sea. J Mar Biol Assoc UK 64: $563-572$

Smith JW, Wootten R (1984) Anisakis larvae ('Herringworm') (Nematoda) in fish. Fiche No. 8, ICES, Copenhagen

St. Hilaire S, Gubbins M, Bayley A (2005) Investigation of a wild fish kill on the River Tyne. Fish Vet J 8:107-113

Submitted: February 12, 2008; Accepted: August 25, 2008

Proofs received from author(s): October 10, 2008 